\title{
Phylogenetic interrelations between serological variants of Bacillus thuringiensis
}

\author{
T.I. Patyka, N.V. Patyka, V.F. Patyka
}

State Institution All-Russia Scientific Research Institute for Agricultural Microbiology RAAS, Saint-Petersburg, Pushkin

${ }^{1}$ D.K. Zabolotny Institute of Microbiology and Virology, NAS of Ukraine

154 Academician Zabolotny Str., Kyiv 03680 Ukraine

vpatyka@mail.ru, patykatatyana@mail.ru

\begin{abstract}
Aim. B. thuringiensis (Bt) are gram-positive spore-forming aerobic or facultative anaerobic bacteria able to form during sporulation species specific crystal-like inclusions of protein nature, consisting of particular thermolabile $\delta$-endotoxins. Serological Bt variants produce different entomotoxins; their synthesis in many respects depends on the conditions of cultivation. There was accumulated a vast information on the entomotoxins, their origin, synthesis, structure, toxic properties and mechanisms of action on insects. These bacteria are dominating in the microbiomethods of pest control in plants and animals. There are more than 70 serovariants of Bt selectively specific to the definite groups of host insects. However, the description of new variants not always looks justified considering the phylogenetic systematization based on phenotype signs. Methods. A comparative phylogenetic analysis of the Bt intraspecific interrelations was performed on the basis of the cloned 16S rRNA genes of entomopathogenic bacteria $\mathrm{BtH}_{1}, \mathrm{BtH}_{10}, \mathrm{BtH_{14 }}$. Results. The phylogenetically homogeneous lines were investigated - a homology of $16 \mathrm{~S}$ rRNA of the strains 1 and 10 ranged from 90,0 to 94,0\%; no distinct genetic isolation among the strains of $14^{\text {th }}$ and $10^{\text {th }}$ serovars was revealed. Conclusions. The comparison of nucleotides sequences of $16 S$ rRNA has shown the existence of strains polymorphism within the group of entomopathogens $\mathrm{BtH}_{1}, \mathrm{BtH}_{10}, \mathrm{BtH_{14 }}$, connected with their entomocide activity.
\end{abstract}

Keywords: serovars, Bacillus thuringiensis, phylogenetic analysis.

Introduction. The use of genome or its fragments in the systematization of microorganisms is of special importance due to its relative conservatism compared to any other features; besides, genetic differences better reflect evolutionary formed relations between microorganisms, which makes them a good foundation for modern classification of bacteria.

(C) Institute of Molecular Biology and Genetics NAS of Ukraine, 2009
The application of the methods of evaluating genetic similarity (comparative DNA analysis and analysis of amino acid sequences of proteins) allows extending the possibilities of researchers in creating molecular evolutionary systematics and phylogeny of bacteria. The phylogeny of a group of organisms is traditionally presented in the form of hierarchic "tree", reflecting possible evolutionary relations $[1,2]$. The application of molecular and genetic approaches in 
The list of Bacillus thuringiensis strains, used in the study

\begin{tabular}{c|c|c|c|c}
\hline Variant & Serovariant & Number of strains & $\begin{array}{c}\text { Abbreviated name } \\
\text { (according to the } \\
\text { catalogue of Institute } \\
\text { Pasteur) }\end{array}$ & Functional group \\
\hline $\begin{array}{c}\text { thuringiensis } \\
\text { darmstadiensis } \\
\text { israelensis }\end{array}$ & $10 \mathrm{a}, 10 \mathrm{~b}$ & 5 & THU & DAR I IV IV \\
\hline
\end{tabular}

microbiology resulted in the establishment of several directions in the systematization of bacteria, in particular, the formation of phylogenetic systematization of bacteria, identification of strains using phylogenetic and phenotypic information, and detection of microorganisms in the environment without their cultivation. It allows controlling the purity of biopreparations, based on active, technological strains, and monitoring cultures in corresponding conditions. There is a need for foundation of further studying on genotype of cultures, promising for biotechnologies, as well as for the search and detection of genes, predetermining high biological activity.

B. thuringiensis (Bt) are gram-positive spore-forming aerobic or facultative anaerobic bacteria able to form species specific crystal-like inclusions of protein nature, consisting of particular thermolabile $\delta$-endotoxins, during sporulation. Serological Bt variants produce different entomotoxins; in many respects their synthesis depends on the conditions of cultivation. There was accumulated a vast information on the entomotoxins, their origin, synthesis, structure, toxic properties, and mechanisms of their action on insects.

$B t$ strains are pathogenic for larvae of Colorado potato beetle, younger larvae of Mamestra brassicae, Pieris brassicae, Plutella maculipennis, Phyllotreta atra $F$. and Brevicoryne brassicae on vegetables. They are highly remarkable for their activity against populations of Yaponomeuta padellus L., Hyphantria cunea Drury, Archips crataegana Hb., Malacosoma neustria L., Ocneria dispar L., Dendrolimus pini L., D. sibiricus, Operophtera brumata Cl., Erannis difoliaria L., Euproctis chrysorrhoea, E. karghalica M. on fruit trees; Tetranychus urticae Koch., T. telarius L. on cucumbers in protected soil; caterpillar of Loxostege sticticalis $L$. on beets, carrots, cabbage, sunflower and permanent grasses; caterpillar of Tortrix viridana $L$. on vineyards and many other pests [3].

Therefore, $B t$ are dominating in the microbiomethods of pest control in plants and animals. There are more than 70 serovariants of $B t$, selectively specific to the definite groups of host insects. However, the description of new variants does not always seem justified considering the phylogenetic systematization based on phenotype features.

The current work is aimed at phylogenetic analysis of various serological variants of entomopathogenic $B t$ bacteria, isolated from natural populations of insects, which is based on the study on polymorphism of nucleotide sequences of 16S rRNA genes.

Materials and Methods. The different strains of entomopathogenic $B t$ bacteria, isolated from natural populations of insects, were used in the work, namely, exotoxinogenic $B t$ var. thuringiensis $\left(B t H_{1}\right), B t$ var. darmstadiensis $\left(B t H_{10}\right), B t$ var. israelensis $\left(B t H_{14}\right)$ (Table).

The DNA of entomopathogenic bacteria was extracted using the method, described in [4]. After electrophoretic separation in $1 \%$ agarose gel the samples of DNA obtained were visually detected as described in [5]. Polymerase chain reaction (PCR) for 16S rRNA was performed according to the standard procedure in the amplifier BioRad My Cycler, using oligonucleotides

SSU-642-F HAATHYGTGCCAGCAGC and SSU-1445-R GTCRTCCYDCCTTCCTC. After extraction from 1\% agarose gel the products of amplification were used for cloning in vector $p A L-T A[6,7]$. 


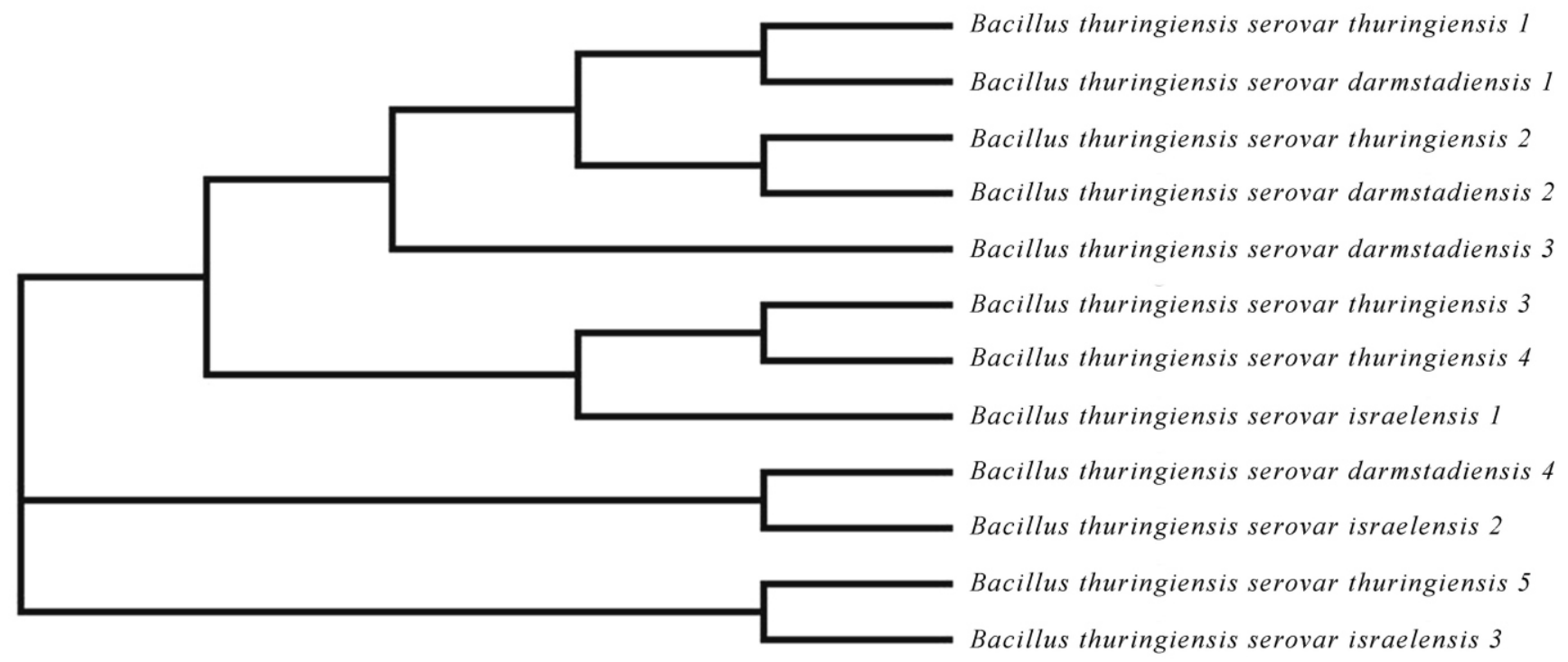

Phylogenetic interrelation of $B t$ variants, based on the analysis of sequences of $16 \mathrm{~S}$ rRNA genes

Automatic sequencer CEQ 8000 Genetic Analysis System (Beckman Coulter, USA) was used to analyse nucleotide sequences and to check their identity to corresponding sequences of $16 \mathrm{~S}$ rRNAs of various $B t$ variants from the GenBank database. Obtained nucleotide sequences were used to build the dendrogram and to estimate the similarity of serological variants by Vector NTI Advance 8.0 software.

Results and Discussion. The phylogenetic analysis is based on the comparison of genes or proteins, similar in structure or functions, starting with their primary sequences. The analysis of $16 \mathrm{~S}$ rRNA proved to be a more efficient molecular and taxonomic means in evaluating genetic variety and relations between bacterial kinds (serotypes) of $B t$ entomopathogens, compared to approaches, based on phenotypic data (e.g. serotyping by $H$-antigen). However, it is noteworthy that reconstructions of phylogenetic relations between strains, conducted on the basis of different molecular data are not always in good agreement with "morphological" classification or among themselves. The main reasons of divergence of morphological and molecular reconstructions are based on the fact that only a small part of genetic information, enclosed in the genome of the organism, is revealed on the morphological level. The combination of data of the study on 16S rRNA may be used to obtain visually evident fingerprints and to confirm species membership of strains and phylogenetic interrelations inside the specific species.

The dendrogram, built on the basis of data obtained (Figure), demonstrates existing interrelations between $B t$ strains of the $1^{\text {st }}, 10^{\text {th }}$, and $14^{\text {th }}$ serotypes. Almost all $B t$ types may be divided into groups; they demonstrate phylogenetic similarity, however, there are some evident isolated variants. The topology of dividing bacilli types on the dendrogram testifies to the existence of three main clusters, corresponding to six genotypes. The comparison of $B t$ strains showed that genetically-wise there are three closely-related genotypes of the first cluster with the similarity level of

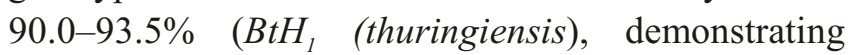
entomocide activity regarding Lepidoptera, and $\mathrm{BtH}$ (darmstadiensis), active against Coleoptera. Thus, genetic homology of entomopathogenic strains is also confirmed by the spectrum of their entomocide activity.

The $\mathrm{BtH}_{14}$ (israelensis) strains, affecting the larvea of Culicidae, gnat and herbovorous mosquitoes 
(Cricotopus silvestris, Licoriella fucorum, etc.) are in the second and the third clusters with the smallest similarity level of $16 \mathrm{~S}$ rRNA (less than $70 \%$ homology). It is noteworthy that the unique effect of israelensis bacteria on the larvae of dipterans, including larvicidal effect, is solely related to the specificities of their crystalline endotoxin.

$B t$ strains, producing various sets of entomotoxins, may vary greatly in their biological activity regarding susceptible insects or show considerable similarities, e.g. some mosquitocide strains, etc. The entomopathogens of the same type are known for their frequently observed similar set of pathogenicity factors as well as for similar biochemical and genome characteristics. However, the descendants of different clones of the same type are specific for some variability both on genotype and phenotype levels.

Therefore, the molecular and genetic analysis of $B t H_{1}, B t H_{10}, B t H_{14}$, based on the comparison of nucleotide sequences of $16 \mathrm{~S}$ rRNA, revealed existence of strain polymorphism within the group of entomopathogens. The differences, defined by morphological, physiological and biochemical, and serological characteristics of $B t$ strains, allow making an interim conclusion on their belonging to at least two phylogenetically homogeneous lines. The similarity level of $16 \mathrm{~S}$ rRNA of strains of the $1^{\text {st }}$ and $10^{\text {th }}$ serotypes is $90.0-94.0 \%$. There was no distinct phylogenetic isolation revealed between the strains of the $10^{\text {th }}$ and $14^{\text {th }}$ serotypes. The reliability of phylogenetic results will depend greatly on the combination of various data which will give a possibility in future to influence the congruence of phylogenetic trees, statistical support, and definition of their branches, eliminating the systematic error.

\section{Т. И. Патыка, Н. В. Патыка, В. Ф. Патыка}

Филогенетические взаимосвязи серологических вариантов Bacillus thuringiensis

Цель. B. thuringiensis (Bt) - грамположительные спорообразующче аэробные или факультативно анаэробные бактерии, способные в процессе споруляции образовывать видоспецифические кристаллообразные включения белковой природы, состоящие из особых термолабильных $\delta$-эндотоксинов. Серологические варианты Bt продуцируют разные энтомотоксины, их синтез во многом зависит от условий культивиро- вания культуры. Накоплен богатый фактический материал о происхождении энтомотоксинов, условиях синтеза, строении, составе, токсических свойствах и механизмах действия на насекомых. Bt приобрели доминантное положение в микробиометоде борьбы с вредителями растений и животных. В настоящее время существуют разновидности Bt в более чем 70 вариантах (серотипах), избирательно специфичных к определенному кругу хозяев-насекомых. Однако описание новых разновидностей не всегда выглядит оправданным с точки зрения филогенетической систематики, основанной на фенотипических признаках. Методы. На основе клонированных генов $16 \mathrm{~S}$ pPHК энтомопатогенных бактерий BtH1, BtH10, BtH14 проведен сравнительный филогенетический анализ внутривидовых взаимосвязей Bt. Результаты. Прослежены филогенетически однородные линии (уровень сходства 16 р рРНК штаммов 1-го и 10-го серотипов составляет от 90,0 до 94\%; отчетливой генетической обособленности среди итаммов 10-го и 14-го серотипов не выявлено). Выводы. При сравнении нуклеотидных последовательностей по $16 \mathrm{~S}$ рРНК установлено существование штаммового полиморфизма внутри группь энтомопатогенов BtH1, BtH10, BtH14, связанного с их энтомоцидной активностью.

Ключевые слова: сероварианты, Bacillus thuringiensis, филогенетический анализ.

\section{Т. І. Патика, М. В. Патика, В. П. Патика}

Філогенетичні взаємозв'язки серологічних варіантів Bacillus thuringiensis

Резюме

Mema. B. thuringiensis (Bt) - грампозитивні спороутворюючі аеробні або факультативно анаеробні бактерії, здатні в проиесі споруляиї формувати видоспецифічні кристалоподібні включення білкової природи, які складаються з особливих термолабільних $\delta$-ендотоксинів. Серологічні варіанти Bt продукують різні ентомотоксини, синтез їх багато в чому залежить від умов культивування культури. Накопичено багатий фактичний матеріал щодо походження ентомотоксинів, умов синтезу, будови, складу, токсичних властивостей і механізмів дії на комах. Вt набули домінантного положення у мікробіометоді боротьби із шкідниками рослин $і$ тварин. На сьогодні існують різновиди Bt у більи ніж 70 варіантах (серотипах), вибірково специфічних до певного кола хазяїв-комах. Однак опис нових різновидів не завжди є виправданим з точки зору філогенетичної систематики, основаної на фенотипових ознаках. Методи. На базі клонованих генів $16 \mathrm{~S}$ рРНК ентомопатогенних бактерій BtH1, ВtH10, ВtH14 здійснено порівняльний філогенетичний аналіз внутрішньовидових взаємозв'язків Bt. Результати. Прослідковано філогенетично однорідні лінії (рівень схожості $16 \mathrm{~S} \mathrm{pPHК} \mathrm{штамів} \mathrm{1-го} \mathrm{и} \mathrm{10-го} \mathrm{серотипів} \mathrm{ста-}$ новить від 90,0 до 94 \%; чіткого генетичного виокремлення итамів 10-го і 14-го серотипів не визначено). Висновки. При порівнянні нуклеотидних послідовностей за $16 \mathrm{~S}$ рРНК встановлено існування штамового поліморфізму всередині групи ентомопатогенів BtH1, BtH10, ВtH14, пов'язаного 3 їхньою ентомоциидню активністю.

Ключові слова: сероваріанти, Bacillus thuringiensis, філогенетичний аналіз. 


\section{REFERENCES}

1. Blokhina I. N., Livanova G. F., Antonov A. S. Sistematika bakteriy (s osnovami genosistematiki).-N. Novgorod, 1992.$170 \mathrm{~s}$.

2. Spaink G., Kondorosi A., Hooykaas P. The Rhizobiaceae: Molecular biology of model plant-associated bacteria.Dordrecht: Kluwer Acad. publ.-566 p.

3. Kandybin N. $V$. Bakterial'nye sredstva bor'by s gryzunami i vrednymi nasekomymi: teoriya i praktika.-M.: Agropromizdat, 1989.-172 s.

4. Doyle J. J., Doyle J. L. Isolation of plant DNA from fresh tissue // Focus.-1987.-12.-P. 13-15.
5. Moreira D. Efficient removal of PCR inhibitors using agarose-embedded DNA preparations // Nucl. Acids Res.-1998.26, N 13.-P. 3309-3310.

6. Joung K.-B., Cote J.-C. Phylogenetic analysis of Bacillus thuringiensis serovars based on $16 \mathrm{~S}$ rRNA gene restriction fragments length polymorphizm // Appl. Microbiol.-2001.90.-P. 115-122.

7. Maniatis T., SambrookJ., Fritsch E. F. Molecular cloning: A laboratory manual.-New York: Cold Spring Harbor Lab. publ., 1982.-545 p.

UDC 632.937

Received 26.05.08 